\title{
Alternative splicing signatures discriminate ATL cells from untransformed CD4+ counterparts deriving from HTLV-1 infected individuals
}

\author{
Morgan Thenoz ${ }^{1 *}$, Céline Vernin ${ }^{1}$, Christiane Pinatel $^{2}$, Nicolas Nazaret ${ }^{3}$, Joel Lachuer ${ }^{3}$, Antoine Gessain ${ }^{4}$, \\ Didier Auboeuf, Eric Wattel ${ }^{1}$, Franck Mortreux ${ }^{1}$
}

From 16th International Conference on Human Retroviruses: HTLV and Related Viruses

Montreal, Canada. 26-30 June 2013

The clonal expansion and malignant transformation of HTLV-1 infected CD4+ T-cells have been linked to the reprogramming effects of HTLV-1 on host transcriptional profile. Coupled to transcription, alternative splicing (AS) is a post-transcriptional process that plays critical role in the complexity of transcriptome and splicing abnormalities frequently occur in cancer. To examine whether AS modifications associate with HTLV-1-associated leukemogenesis, we compared the exon expression profiles of ATL cells with that of CD4+ T-cell clones obtained by limited-dilution cloning of PBMC deriving from HTLV-1 carriers. 3 ATL cells and 12 untransformed infected clones clustering in infected, uninfected, PHA-stimulated or unstimulated $\mathrm{CD} 4+\mathrm{T}$ cells were compared for exon RNA content using Exon Chip Human microarray. Hierarchical clustering analysis identified 12516 alternative spliced events (3642 genes) that clearly separated ATL samples from the 4 untransformed phenotypes mentioned above. In contrast, the exon content of 1539 genes differed between untransformed infected and uninfected T-CD $4+$ cells. Overall, less than $5 \%$ alternatively spliced genes were found differentially expressed at the transcriptional level. Microarray data were confirmed for 18 AS events using exon specific RT-PCR analysis. Pathway analysis of alternatively spliced genes (3642) in ATL cells revealed new AS-based pathways for p53 signaling, cell cycle and DNA replication while those of untransformed infected CD4+ T-cells were enriched in pathways for cellular movement and DNA repair. These findings unveil a new layer of complexity in the interplay between HTLV-1 and host cell gene expression

'Oncovirologie et Biotherapies, UMR5239 CNRS/ENS Lyon/UCBL/HCL, Hopital Pierre Benite, Lyon, France

Full list of author information is available at the end of the article machinery in which AS might play a central role in tumor initiation and promotion.

\section{Authors' details}

'Oncovirologie et Biotherapies, UMR5239 CNRS/ENS Lyon/UCBL/HCL, Hopital Pierre Benite, Lyon, France. ${ }^{2}$ Oncovirologie et Biothérapies, Centre Léon Bérard, Lyon, France. ${ }^{3}$ ProfileXpert, Neurobiotec Service, Bron, France. ${ }^{4}$ Unit of Epidemiology and Physiopathology of Oncogenic Viruses, Department of Virology, Institut Pasteur, Paris, France. Institut National de Santé et de Recherche Médicale U590, Centre Léon Bérard, Lyon, France.

Published: 7 January 2014

doi:10.1186/1742-4690-11-S1-066

Cite this article as: Thenoz et al: Alternative splicing signatures discriminate ATL cells from untransformed CD4+ counterparts deriving from HTLV-1 infected individuals. Retrovirology 2014 11(Suppl 1):O66.

\section{Submit your next manuscript to BioMed Central and take full advantage of: \\ - Convenient online submission \\ - Thorough peer review \\ - No space constraints or color figure charges \\ - Immediate publication on acceptance \\ - Inclusion in PubMed, CAS, Scopus and Google Scholar \\ - Research which is freely available for redistribution

